\title{
Biliary tract cancer and occupation in Sweden
}

\author{
H S R MALKER, ${ }^{1}$ J K MCLAUGHLIN, ${ }^{2}$ BIRGITTA K MALKER, ${ }^{3}$ B J STONE, ${ }^{2}$ \\ J A WEINER, ${ }^{1}$ J L E ERICSSON, ${ }^{3}$ AND W J BLOT ${ }^{2}$
}

From the National Board of Occupational Safety and Health, ${ }^{1}$ Solna, S-171 84, Sweden, Biostatistics Branch, ${ }^{2}$ Epidemiology and Biostatistics Program, Division of Cancer Etiology, National Cancer Institute, Bethesda, Maryland 20205, USA, and National Board of Health and Welfare, ${ }^{3}$ Stockholm, S-106 30, Sweden

ABSTRACT Using the Cancer-Environment Registry, which links the incidence of cancer (1961-79) and the 1960 census data on industry and occupation for all employed individuals in Sweden, the occurrence of biliary tract cancer (ICD 7 th rev $155 \cdot 1-9$ ) was systematically assessed according to occupational and industrial classifications. Data are presented separately for cancer of the gall bladder (ICD 155.1) and other cancers of the biliary tract (ICD 155.2-.9) including cancers of the extrahepatic bile ducts, ampulla of Vater, and unspecified bile passages. Statistically significant increased risks for cancer of the gall bladder were observed for men employed in petroleum refining, papermills, chemical processing, shoemaking, and repairing, and for both men and women employed in textile work. A significant increase in the incidence of other cancers of the biliary tract (mostly cancers of the bile duct) was found for such asbestos related employment as shipbuilding and in the wholesale construction materials industry and among insulation workers. These findings should be considered only as clues to aetiological factors, although several are consistent with earlier observations from other countries.

There have been few investigations of cancer of the biliary tract and occupation. ${ }^{1}$ Nearly 15 years ago, associations were reported for rubber workers ${ }^{2} 3$ and automotive workers ${ }^{3}$ for both cancer of the gall bladder and of the bile duct (including the ampulla of Vater). Textile and metal fabricating workers also were reported to have raised mortality rates from cancer of the gall bladder whereas workers in the aircraft, chemical, and woodfinishing industries were noted to have raised rates of cancer of the bile duct ${ }^{3}$; to our knowledge there have been no reports of subsequent investigations exploring these and other occupational clues. The Cancer-Environment Registry (CER), ${ }^{45}$ which links the incidence of cancer to census derived employment information, affords a unique opportunity to assess systematically the occurrence of biliary tract cancer by employment category within an entire country. We report here results from this hypothesis generating investigation, the first systematically to evaluate occupational risks for biliary tract cancer using incidence data in a large scale population based manner.

\section{Methods}

The CER links occupational information from the Accepted 15 August 1985
1960 census with the cancer incidence data (1961-79) of the National Swedish Cancer Registry (NSCR). All Swedish citizens have a unique personal identification number that allows for linkage between these two data sources. Ascertainment of biliary tract cancers (ICD 7th rev 155.1-.9) in Sweden is essentially complete as national law requires the reporting of all malignant tumours and certain precancerous lesions to the NSCR. ${ }^{6}$ For the period under investigation (1961-79), $93 \%$ of all biliary tract cancers were microscopically verified.

A standardised cumulative (19 years) incidence ratio (SIR) was used to estimate the risk of biliary tract cancer for various occupational and industrial groupings. The SIR is the ratio of the observed number of cases of biliary tract cancer in a particular industry or occupation to the expected number of cases. The expected number of cases of biliary tract cancer is generated by applying the five year birth cohort and sex specific rates for 1961-79 of the general Swedish population to the five year birth cohort and sex specific distributions of the various occupational and industrial categories. As the result of geographical variations in the incidence of cancer in Sweden, all SIR calculations were adjusted for region. ${ }^{7}$ Statistical significance was tested under the assumption that the observed number of cases of biliary tract cancer followed a Poisson distribution. ${ }^{8}$ Employment 
Table 1 Standardised incidence ratios (SIR) for gall bladder cancer and other biliary tract cancer by major divisions of industry and occupation among men

\begin{tabular}{|c|c|c|c|c|c|}
\hline Code & Major industry & $\begin{array}{l}\text { Gall bladder } \\
\text { cancer cases }\end{array}$ & $S I R^{*}$ & $\begin{array}{l}\text { Other biliary } \\
\text { cancer cases }\end{array}$ & $S I R+\frac{\overline{\bar{C}}}{\overline{0}}$ \\
\hline $\begin{array}{l}0 \\
1 \\
2 \\
3 \\
4 \\
5 \\
6 \\
7 \\
8 \\
9\end{array}$ & $\begin{array}{l}\text { Farming, forestry, hunting, and fishing } \\
\text { Mining and quarrying } \\
\text { Manufacturing I } \\
\text { Manufacturing II } \\
\text { Construction } \\
\text { Electric, gas, water, and sanitary services } \\
\text { Trade, finance, insurance, and real estate } \\
\text { Transportation and communication } \\
\text { Services } \\
\text { Non-classifiable establishments }\end{array}$ & $\begin{array}{r}206 \\
4 \\
224 \\
262 \\
179 \\
22 \\
163 \\
90 \\
149 \\
5\end{array}$ & $\begin{array}{l}0 \cdot 7 \dagger \\
0 \cdot 4 \\
1 \cdot 2 \dagger \\
1 \cdot 0 \\
1 \cdot 0 \\
1 \cdot 1 \\
1 \cdot 2 \ddagger \\
1 \cdot 0 \\
1 \cdot 1 \\
1 \cdot 3\end{array}$ & $\begin{array}{r}143 \\
8 \\
109 \\
145 \\
114 \\
15 \\
96 \\
61 \\
72 \\
1\end{array}$ & 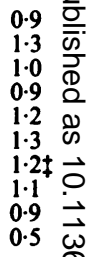 \\
\hline
\end{tabular}

*Adjusted for age and region.

tp $<0.01$.

$\pm \mathrm{p}<0.05$.

NEC $=$ Not elsewhere classified.

Table 2 Standardised incidence ratios (SIR) for gall bladder cancer and other biliary tract cancers for general ( $t$ wo digit) manufacturing industries and craftsmen-tradesmen occupations among men

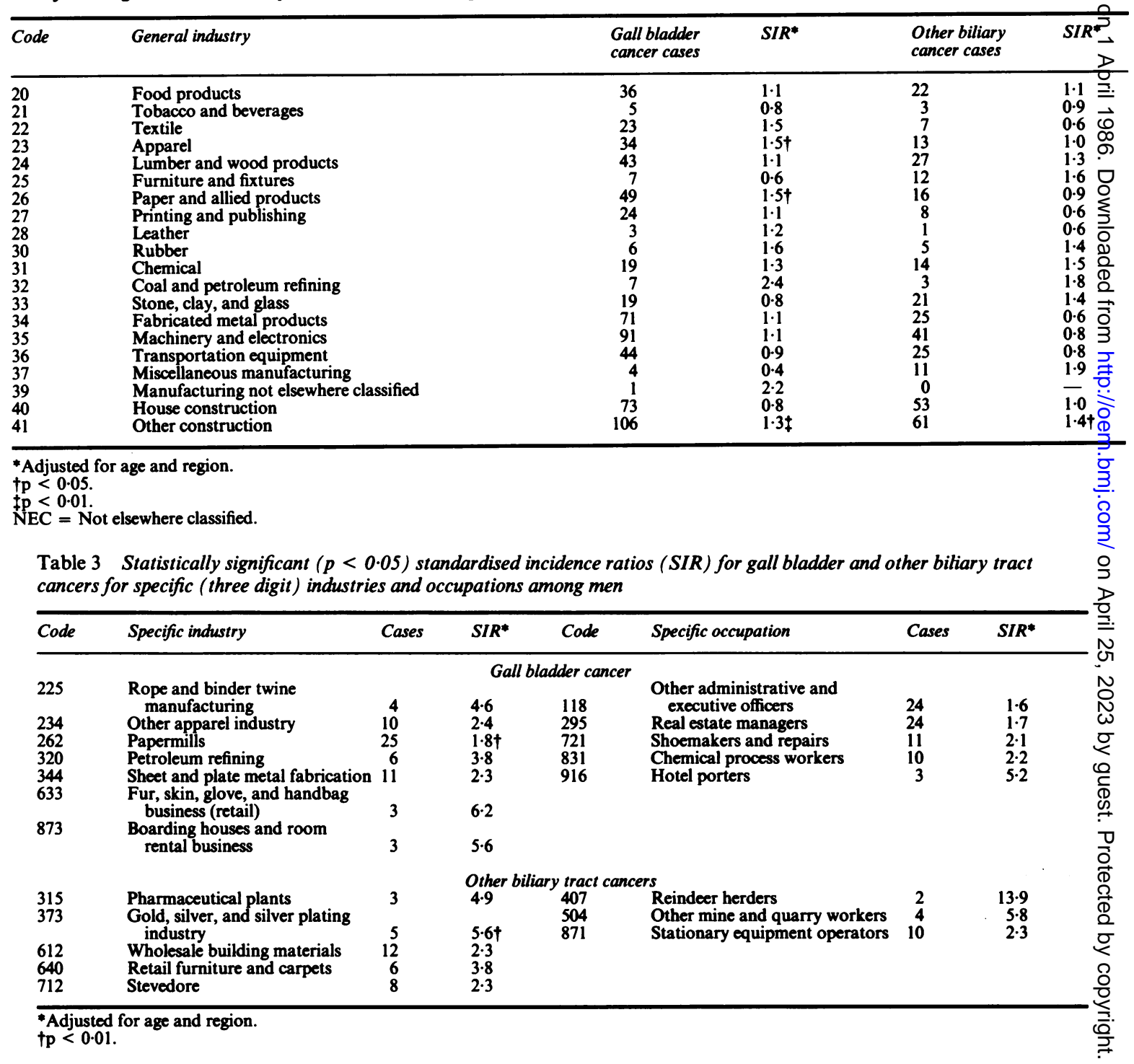




\begin{tabular}{|c|c|c|c|c|c|}
\hline Code & Major occupation & $\begin{array}{l}\text { Gall bladder } \\
\text { cancer cases }\end{array}$ & $S I R^{*}$ & $\begin{array}{l}\text { Other biliary } \\
\text { cancer cases }\end{array}$ & $S I R^{*}$ \\
\hline $\begin{array}{l}0 \\
1 \\
2 \\
3 \\
4 \\
5 \\
6 \\
7 \\
8 \\
9\end{array}$ & $\begin{array}{l}\text { Professional, technical, and related workers } \\
\text { Administrative, executive, and managerial workers } \\
\text { Clerical workers } \\
\text { Sales workers } \\
\text { Farmers, fishermen, hunters, and related workers } \\
\text { Miners, quarrymen, and related workers } \\
\text { Transport and communication workers } \\
\text { Craftsmen, production process workers, and labourers } \\
\text { Craftsmen, production process workers, and labourers, NEC } \\
\text { Service, sport, and recreation workers }\end{array}$ & $\begin{array}{r}159 \\
64 \\
65 \\
98 \\
199 \\
5 \\
79 \\
350 \\
208 \\
77\end{array}$ & $\begin{array}{l}1 \cdot 2 \dagger \\
1 \cdot 2 \\
1 \cdot 2 \\
1 \cdot 1 \\
0 \cdot 7 \dagger \\
0 \cdot 6 \\
0 \cdot 9 \\
1 \cdot 0 \\
1 \cdot 1 \\
1 \cdot 3 \dagger\end{array}$ & $\begin{array}{r}75 \\
26 \\
36 \\
60 \\
138 \\
8 \\
56 \\
207 \\
127 \\
31\end{array}$ & $\begin{array}{l}0.9 \\
0.9 \\
1.2 \\
1.2 \\
0.9 \\
1.8 \\
1.1 \\
1.0 \\
1.2 \\
0.9\end{array}$ \\
\hline
\end{tabular}

\begin{tabular}{|c|c|c|c|c|c|}
\hline Code & General occupation & $\begin{array}{l}\text { Gall bladder } \\
\text { cancer cases }\end{array}$ & $S I R^{*}$ & $\begin{array}{l}\text { Other biliary } \\
\text { cancer cases }\end{array}$ & $S I R^{*}$ \\
\hline $\begin{array}{l}70 \\
71 \\
72 \\
73 \\
74 \\
75 \\
76 \\
77 \\
78 \\
79 \\
80 \\
81 \\
82 \\
83 \\
84 \\
85 \\
86 \\
87 \\
88\end{array}$ & $\begin{array}{l}\text { Spinners, weavers, and knitters } \\
\text { Tailors, cutters, furriers } \\
\text { Shoe and leather workers } \\
\text { Metal making and treating workers } \\
\text { Precision instrument makers } \\
\text { Toolmakers, machinists, plumbers, and welders } \\
\text { Electricians and electronic workers } \\
\text { Woodworkers } \\
\text { Painters and paperhangers } \\
\text { Bricklayers and construction workers NEC } \\
\text { Graphical workers } \\
\text { Potters, kilnmen, and glass workers } \\
\text { Food industry workers } \\
\text { Chemical and cellulose workers } \\
\text { Tobacco workers } \\
\text { Craftsmen and production process workers } \\
\text { Labourer NEC } \\
\text { Stationary engine and equipment operators } \\
\text { Packers, handlers, and longshoremen }\end{array}$ & $\begin{array}{r}11 \\
19 \\
14 \\
22 \\
6 \\
109 \\
27 \\
67 \\
32 \\
43 \\
14 \\
4 \\
22 \\
28 \\
0 \\
12 \\
55 \\
21 \\
52\end{array}$ & $\begin{array}{l}1.5 \\
1.7 \dagger \\
1.5 \\
0.9 \\
1.1 \\
1.1 \\
1.1 \\
0.8 \\
1.3 \\
0.8 \\
1.2 \\
1.2 \\
1 \cdot 1 \\
1.4 \\
0.9 \\
1.3 \\
0.8 \\
1.1\end{array}$ & $\begin{array}{r}4 \\
8 \\
7 \\
10 \\
5 \\
53 \\
18 \\
45 \\
19 \\
38 \\
3 \\
4 \\
17 \\
12 \\
0 \\
14 \\
25 \\
19 \\
33\end{array}$ & $\begin{array}{l}0.7 \\
1.3 \\
1.4 \\
0.7 \\
1.6 \\
0.8 \\
1.2 \\
0.9 \\
1.4 \\
1.2 \\
0.4 \\
1.0 \\
1.4 \\
1.0 \\
1.5 \\
1.0 \\
1.3 \\
1.2\end{array}$ \\
\hline
\end{tabular}

Table 4 Statistically significant $(p<0.05)$ standardised incidence ratios $(S I R)$ for gall bladder and other biliary tract cancers for specific (three digit) industries and occupations among women

\begin{tabular}{|c|c|c|c|c|c|c|c|}
\hline Code & Specific industry & Cases & $S I R^{*}$ & Code & Specific occupation & Cases & $S I R^{*}$ \\
\hline 845 & Other public service NEC & 7 & $3 \cdot 3^{G a l}$ & $\begin{array}{l}\text { dder can } \\
095 \\
772\end{array}$ & $\begin{array}{l}\text { Psychologists and personnel } \\
\text { directors } \\
\text { Cabinet makers }\end{array}$ & $\begin{array}{l}6 \\
3\end{array}$ & $\begin{array}{l}4 \cdot 4 \\
5 \cdot 7\end{array}$ \\
\hline $\begin{array}{l}233 \\
360 \\
378 \\
808 \\
843\end{array}$ & $\begin{array}{l}\text { Apparel industry } \\
\text { Shipbuilding and repair } \\
\text { Other fabrication industries } \\
\text { Other community administration } \\
\text { Advertising and marketing }\end{array}$ & $\begin{array}{r}20 \\
3 \\
4 \\
7 \\
3\end{array}$ & $\begin{array}{l}\text { Other } \\
1.8 \\
7.3 \\
4.9 \\
2.5 \\
8.9+\end{array}$ & $\begin{array}{l}y \text { tract } \\
716\end{array}$ & ${ }^{e r}$ Garment makers & 24 & $2 \cdot 1 \dagger$ \\
\hline
\end{tabular}

*Adjusted for age and region.

NEC $=$ Not elsewhere classified . 
classifications from the 1960 census were used to define the industrial and occupational groups. ${ }^{9}$ These categories are revised versions of the standards from the International Labour Office ${ }^{10}$ and the United $\mathrm{Na}$ tions. ${ }^{11}$ SIRs were calculated for all major (one digit) and general (two digit) industrial and occupational codes. For specific (three digit) employment categories only those with 500 or more individuals were evaluated, as there are over 300 industrial and 300 occupational categories at the three digit level. When informative, the risk of biliary tract cancer was assessed for occupations within industries to allow for a more detailed evaluation of risk.

\section{Results}

There were 1304 cases of gall bladder cancer and 764 cases of other biliary tract cancers during the 19 year follow up of Swedish men employed in 1960. Of the 764 cases of other biliary tract cancers, $479(63 \%)$ were tumours of the bile ducts and $230(30 \%)$ tumours of the ampulla of Vater.

Table 1 shows the SIRs for gall bladder and other biliary tract cancers separately for the major divisions of industry and occupation in Sweden for men. For major industries, moderately increased but statistically significant risks were found for gall bladder cancer in manufacturing (industry 2), and for both gall bladder and other biliary tract cancers in trade, finance, insurance, and real estate (ind 6). For major occupations, significantly raised SIRs were observed for gall bladder cancer among professional and technical workers (occupation 0), and service, sport, and recreation workers (occ 9). Significantly decreased SIRs for gall bladder cancer were observed in the farming and fishing industry (ind 0 ) and among farmers and related workers (occ 4).

Because of the a priori possibility of occupational exposure to potential carcinogens, SIRs for general (two digit) manufacturing industries and craftsmentradesmen occupations are shown in table 2. Men employed in the apparel (ind 23), paper and allied products (ind 26), and other construction (ind 41) industries had a significantly increased risk of gall bladder cancer as did tailors, cutters, and furriers (occ 71). The only significantly raised SIR for other biliary tract cancers was for men employed in the other construction industry (ind 41).

The significantly raised $(p<0.05)$ SIRs associated with gall bladder cancer for specific (three digit) industries and occupations are shown in table 3 (top panel). Risks of about fourfold or greater were observed for several categories, although all were based on small numbers of observed cases. Statistically significant SIRs for other biliary tract cancers are shown in the lower panel of table 3. High SIRs were also found in several categories but few cases were affected.

There were several statistically significant associations for occupations within industries for gall bladder cancer. Tailors (occ 711) in the other apparel industry (ind 234) accounted for all of the raised risk in that industry (SIR $=2.7 ; 10$ cases). Heavy labourers (occ 861) in highway construction (ind 415) were at increased risk (SIR $=1 \cdot 7 ; 26$ cases) as were building caretakers (occ 931) in the real estate industry (ind 680) (SIR $=2 \cdot 1 ; 13$ cases). For other biliary tract cancers significant risks were associated with carpet makers (occ 714) in the carpet making industry (ind $251)(\mathrm{SIR}=4.5 ; 4$ cases) and insulation workers (occ 794) in the other construction industry (ind 416) (SIR $=10 \cdot 6 ; 2$ cases).

There were 947 cases of gall bladder cancer and 346 cases of other biliary tract cancers among Swedish women employed in 1960. Of the other cases of biliary tract cancer, $231(67 \%)$ had tumours of the bile ducts and $78(23 \%)$ tumours of the ampulla of Vater. Table 4 shows the statistically significant SIRs among women employed in 1960 . Most notable were the increased risks for other biliary tract cancers with employment in the apparel industry and for the occupation of garment making. The risk of gall bladder cancer for women employed in papermills was also raised, (SIR $=1.9 ; 9$ cases).

\section{Discussion}

This study has produced several statistically significant occupational associations for gall bladder and other biliary tract cancers. Although some may be chance findings due to the multiple comparisons, others may represent new leads as to the causes of these little studied cancers.

The increased SIR for gall bladder cancer among male textile and apparel workers is consistent with results from an earlier mortality study in California. ${ }^{3}$ The present study also showed an increased risk of bile duct and other biliary cancers among women employed in the apparel industry, raising the possibility that risk may extend to more than one area of the biliary tract. As in the earlier report, ${ }^{3}$ mild increases in the biliary tract cancers were associated with the chemical industry, with the increase exceeding twofold for gall bladder cancer among chemical process workers. The observation of a raised risk among rubber workers (SIR $=1.6$ for gall bladder cancer and 1.4 for other biliary tract cancers) also confirms the earlier findings. The increases, however, were not statistically significant. The earlier investigation also reported significant increases of gall bladder cancer associated with metal fabrication workers, of bile duct cancer with woodworking and aircraft manu- 
facturing, and of both cancers with automotive manufacturing. ${ }^{3}$ The Swedish data do not confirm these observations, although a significant two fold excess of gall bladder cancer was associated with sheet and plate metal fabrication.

Although there is no direct evidence of an association between exposure to asbestos and biliary tract cancer among insulation workers, ${ }^{1}$ the 10 -fold risk for other biliary tract cancers among insulation workers within the construction industry in Sweden is consistent with a case report of asbestos fragments in the cancerous bile duct of an asbestos factory worker. ${ }^{12}$ The finding of a raised SIR for other biliary tract cancers among employees in the wholesale building materials industry may also be linked to exposure to asbestos, as may the excess risk among women employed in shipbuilding. Raised biliary cancer mortality has not been reported among petroleum refinery workers, ${ }^{13}$ although risk ratios for this cancer often included deaths from liver cancer. The nearly fourfold excess of gall bladder cancer among men in the petroleum refining industry and the increase of gall bladder cancer among both men and women employed in papermills are new findings and may warrant follow up with more specific investigations of these groups.

The results of this record linkage study may provide clues to the occupational determinants of biliary tract cancers, although limitations of the CER preclude making causal inferences about the role of occupation in aetiology of cancer. ${ }^{14}$ For example, there is no information on the duration of employment or on other risk factors such as gall stones that may influence the risk of biliary tract cancer.

In evaluating the results of this study the problem of multiple comparisons must be recognised. The problem is particularly acute when there are few a priori leads and a large number of employment categories are reviewed. It is thus difficult to know whether to place much credibility on statistically significant associations for specific (three digit) industries or occupations when over 500 such groups were studied for each of the two cancers, and many associations are expected on the basis of chance alone. Nevertheless, it is noteworthy that several of the findings were consistent with the few earlier published findings for these cancers.

The approach used here has also been applied to pleural mesothelioma and nasal cancer, and well established occupational determinants were correctly identified - for example, mesothelioma and shipyard employment $^{14}$ and nasal cancer and furniture making. ${ }^{15}$ The ability to detect known occupational associations raises confidence in the sensitivity of the approach for cancers such as those of the biliary tract where little is known about their causes. Although some false leads may be produced, we think that the presentation of all the significant associations will help provide hypotheses for future investigations.

No linked registry is better than the quality of its component registries. ${ }^{6}$ In the linkage of the CER only $1 \%$ of the cases of cancer could not be traced in the census. ${ }^{4}$ Incorrect matching of cases of cancer to census information has been estimated to be less than $0.5 \%$. ${ }^{16}$ There may be errors in the census classification, but an independent validation of industrial and occupational data by a reinterview of a random sample of the 1960 census showed close agreement (about $95 \%$ ) at the broad one digit level of coding, with somewhat less agreement for more specific (three digit) codes. ${ }^{17}$ Occupational change is relatively uncommon in Sweden, so the 1960 census information on occupation is likely to represent an individual's usual adulthood job category.

Possibly the statistical techniques used may have influenced the differential risks by industry and occupation. Because of lack of information on loss to follow up, either through departure from Sweden or from death, the expected value for the SIR calculations were not based on "person-years" but rather on the assumption that the proportions of individuals within each sex region birth cohort subgroup from each industry and occupation remained constant over the 19 year follow up. Thus if total mortality was raised (or depressed) for a particular industry or occupation, the expected number of biliary tract cancers, which does not take into account loss due to mortality, would be too high (or low), and the corresponding SIR too low (or high). Such variations, however, have been shown to affect the SIR generally by less than a few percent and thus not seriously alter the interpretation of the data presented. ${ }^{7}$

Requests for reprints to: H S R Malker, National Board of Occupational Safety and Health, Solna, S-171 84, Sweden.

\section{References}

${ }^{1}$ Fraumeni JF Jr, Kantor AF. Biliary tract. In: Schottenfeld D, Fraumeni JF Jr, eds. Cancer epidemiology and prevention. Philadelphia: Saunders, 1982:683-91.

${ }^{2}$ Mancuso TF, Brennan MJ. Epidemiological considerations of cancer of the gallbladder, bile ducts and salivary glands in the rubber industry. J Occup Med 1970;12:333-41.

${ }^{3}$ Krain LS. Gallbladder and extrahepatic bile duct carcinoma. Geriatrics 1972;27:111-7.

${ }^{4}$ Wiklund K, Einhorn J, Wennstrom G, Rappaport E. A Swedish cancer environment registry available for research. Scand $J$ Work Environ Health 1981;7:64-7.

${ }^{5}$ Ahlmark A, Malker H. Potentials for epidemiological studies in occupational medicine. Ann Occup Hyg 1981;24:159-62.

${ }^{6}$ Mattson B, Wallgren J. Completeness of registration in the Swedish cancer registry. Non-notified cancer cases recorded on death certificates in 1978. Acta Radiol Oncol 1984;23:305-13. 
${ }^{7}$ Malker M, Weiner J. The cancer environment registry, 1961-1973. Examples of the use of register epidemiology in studies of the work environment. Arbete och Halsa 1984;9:1-107. (English summary only.)

${ }^{8}$ Bailar JC, Ederer F. Significance factors for the ratio of a Poisson variable to its expectation. Biometrics 1964;20:639-43.

${ }^{9}$ Statistiska Centralbyron och Bostadsstyrelsen. Folk-och Bostadsrakningen. Den 1 November 1960; Redogorelse for Folk-och Bostandsrakningens upplaggning och genomforane. Stockholm: National Central Bureau of Statistics, 1965.

${ }^{10}$ International Labour Office. International standard classification of occupations. Geneva: International Labour Office, 1958.

${ }^{11}$ United Nations Statistical Office. International standard industrial classification of all economic activities. New York: United Nations Statistical Office, 1958.
${ }^{12}$ Szendroi M, Nemeth L, Vajta G. Asbestos bodies in a bile duct cancer after occupational exposure. Environ Res 1983; 30:270-80.

${ }^{13}$ Savitz DA, Moure R. Cancer risk among oil refinery workers. $J$ Occup Med 1984;26:662-70.

${ }^{14}$ Malker HSR, McLaughlin JK, Malker BK, et al. Occupational risks for pleural mesothelioma in Sweden, 1961-79. JNCI 1985;74:61-6.

${ }^{15}$ Malker HSR, McLaughlin JK, Blot WJ, et al. Nasal cancer and occupation in Sweden, 1961-1979. Am J Ind Med (in press).

${ }^{16}$ Eklund G, Wiklund K. Kvalitetskontroll av personidentiiteten i cancermiljoregistret. Statistisk Tidskrift 1979;5:373-6.

${ }^{17}$ Brivkalne M. The control study made in connection with the 1960 census of population. Statistical reports B. Stockholm: National Central Bureau of Statistics, 1964.

\section{Destruction of manuscripts}

From 1 July 1985 articles submitted for publication will not be returned. Authors whose papers are rejected will be advised of the decision and the manuscripts will be kept under security for three months to deal with any inquiries and then destroyed. 